\title{
An Analysis of the First Language Interference in Speaking English of Sixth Semester Students of English Education Study Program of IAIN Bengkulu
}

\author{
Riswanto ${ }^{1, *}$ Detty Lismayanti ${ }^{2}$ Erna Wati ${ }^{3}$ Ixsir Eliya ${ }^{4}$ \\ ${ }^{1234}$ State Islamic University of Fatmawati Sukarno Bengkulu \\ ${ }^{*}$ Corresponding author. Email: ixsir@iainbengkulu.ac.id.
}

\begin{abstract}
This research discusses about first language interference in speaking English of sixth semester students of English Education Study Program of IAIN Bengkulu. It is one of bilingualism aspects that occur when someone is learning English. In this case, the interference of Indonesian into English because the students sometimes use their Indonesian that often contains error when they are speaking English. The purpose of the study is to find out the types of interference and the factors cause interference. The writer focused on speaking English in the classroom discussion. The writer used descriptive qualitative method. Data were collected from observation and interview. The writer selected some sentences included interference by using Weinreich theory and analyzed them. As a result of the research, the writer found that most of students did the interference in words pronounciation that they did not know how to mention the correct vocabulary in English, and in the use of certain vocabulary that they do not know the vocabulary they was apply their Indonesian to the right word to express her mind. So, the writer concluded that interference occurs at linguistic aspects, such as: phonological, and lexical interference and the causes of interference are the lack of knowledge, and the limited vocabularies of target language mastered by the learners. It shows that there are many errors due to language interference that influence bilingual's speech. In other words, their sentences are interfered by their first language, namely Indonesian and those caused by the students who did not master English well.
\end{abstract}

Keywords: First Language, Interference, Speaking

\section{INTRODUCTION}

"Generally, the first language have a different pattern with the second language, it would make some misunderstanding on pronunciation or the speaker of the first language will do some error pronunciation. It is the reason why the first language affects the use of the second language. It may be called language interference. Weinreich [1], states language interference itself is defined as a situation when the person (bilingual) uses norm or rule from their first languages involved to their second language as a result of the language contact on both languages. Interference is the deviation of language norm in usage as the effect of multilingual toward some other languages [3].

Weinreich [1], states that there are three kinds of language interference, they include phonological, grammatical, and lexical. Lekova (2016: 321-322) defines that phonetic interference affects the improper pronunciation of phonetic sounds in the second language caused by the existence of different phonetic structures from the point of view of the mother tongue or the first foreign language.

However, this study was focused on the term phonological and Lexical interference which there is a misappropriate pronunciation because the first language influences the second language. Phonology interference becomes important to be learned due to this kind of interference dealing with speaking skills. Speaking skill is one of the skills that are more noticeable in learning English. Fluently speaking English is useful for communication with a foreign language. Because good speaking will make the listeners understand what we said to them.

For example, in this research, researchers are interested in researching first language interference in speaking English because when researchers conducted 
online pre-observations during at the time of the covid19 pandemic randomly in the sixth-semester Students of class A and B English Department IAIN Bengkulu, there was an error in speaking English, when they pronounce the word (night) / $\mathrm{t} / \mathrm{in}$ "malam" it is replaced by / $\mathrm{k} /$. pronounced with (night). which should have been pronounced (Malam) therefore there is a phonological spelling error.

Based on the above observation, there are three possible assumptions of the problems that can be seen from the students' speaking ability. First, the students are difficult to distinguish among similar sounds. Second, the students are difficulty producing accepted English pronunciation, and the last is they tend to find difficulties in uttering the sounds that Indonesians do not have such as, /ov/ and /3/ which cannot be distinguished clearly in Indonesian, and the sounds are united to be clear /əo/, for example, $/ \mathrm{z} /$ in "zero" /eeziərəo/ and /3/ in "genre"e/za:nrə/. It is then related to the language error. The problems in uttering English by Indonesian students are because their mother tongue (L1) influences their capability in producing English, They only generalize the L2 sounds based on their L1."

\section{RESEARCH METHOD}

The method that is used in this research also is the qualitative method. Parkinson and Drislane in Gregory [4] state that qualitative research is research using methods such as participant observation or case studies that result in a narrative, descriptive account of a setting or practice. This research used the qualitative method because the writer wanted to give a detailed explanation of first language interference in speaking English among the sixth-semester students at the English department of IAIN Bengkulu.

\subsection{Subject of the Research}

There are five classes in the sixth semester of the English Department of the state institute for Islamic Studies (IAIN Bengkulu) in the academic year 2021. However, the subject of this research is sixth-semester students in the English Department sixth class A and B. Class A that have 31 students and class B have 29 students. The Researcher Chose these classes because sixth-semester classes A and B have Sociolinguistics subjects that use full English in their presentation and discussion in the classroom. The researcher did observation in these classes through their presentation, discussion, and communication in the classroom that is used English as their Second Language. The researcher also observed how they speak English in the classroom included their pronunciation or Phonological.

The researcher chose students in sixth-semester classes A and B in the observation sheet and interview session for which was analyzing students speech production, the researcher took seven students per class $\mathrm{A}$ and $\mathrm{B}$ to facilitate data collection. In this research, researchers used random sampling. According to Marshall (1996), random sampling is the research participants were chosen by away if each participant has the same probability to the research of study.

\subsection{Instrument of the Research}

In conducting this research, the writer collected the data by using observation sheets, interviews and Documentations as the instruments. An observation sheet was used for taking important data that related to the first language interference in speaking English at the sixth-semester students class $\mathrm{A}$ and $\mathrm{B}$ at English education IAIN Bengkulu, the interview was used to know factors that cause interference when they are speaking English, and documentation to strengthen the research evidence.

\section{Observation Sheet}

Observation sheet is a way of collecting data with records held on the activities and developments carried out by teachers and students during the learning process.Observation is a spoken or written remark or comment based on something one has seen, heard, etc. It means that the researcher observed what people do, listen to what they say, and participant in their activities by doing observation and data recording systematically.

Table 1. Observation Instrument Grid

\begin{tabular}{|l|l|l|}
\hline Aspects & $\begin{array}{l}\text { Phonological } \\
\text { Interference }\end{array}$ & $\begin{array}{l}\text { Lexical } \\
\text { interference }\end{array}$ \\
\hline $\begin{array}{l}\text { The students use } \\
\text { the English } \\
\text { Language in } \\
\begin{array}{l}\text { Classroom } \\
\text { (presentation, } \\
\text { discussion, and } \\
\text { communication }\end{array}\end{array}$ & $\begin{array}{l}\text { 2. Consonant } \\
\text { and } \\
\text { allophonic } \\
\text { variations }\end{array}$ & $\begin{array}{l}\text {-Vocabulary } \\
\text {-Combine } \\
\text { between } \\
\text { English and } \\
\text { Indonesia } \\
\text { Language }\end{array}$ \\
\hline
\end{tabular}

Observations about first language disorders (Indonesian) made by students when speaking English in class, then grouped what first language disorders were related to their phonological and Lexical Interference.

2. Interview

Interviews are defined by Macmillan and Schumacher (1999), orally with the aim of obtaining data that can explain the problem as encounters between a researcher and respondent. An interview is a process of asking someone's question to get the answer According to Moleong [5] explained that the interview is a conversation with certain intentions. 
Table 2. Interview instrument Grid

\begin{tabular}{|c|c|c|c|c|}
\hline $\begin{array}{l}\mathrm{N} \\
\mathrm{o}\end{array}$ & $\begin{array}{l}\text { Research } \\
\text { Variables }\end{array}$ & $\begin{array}{l}\text { Compon } \\
\text { ent }\end{array}$ & Indicators & $\begin{array}{l}\text { It } \\
\mathrm{e} \\
\mathrm{m} \\
\mathrm{s}\end{array}$ \\
\hline 1. & $\begin{array}{l}\text { First } \\
\text { Language } \\
\text { the } \\
\text { students } \\
\text { use in } \\
\text { everyday }\end{array}$ & $\begin{array}{l}\text { Bahasa } \\
\text { and } \\
\text { vernacul } \\
\text { ar }\end{array}$ & $\begin{array}{l}\text { The Dominant } \\
\text { of the first } \\
\text { language }\end{array}$ & 1 \\
\hline 2. & $\begin{array}{l}\text { A factor of } \\
\text { first } \\
\text { language } \\
\text { interferenc }\end{array}$ & $\begin{array}{l}\text { Phonolog } \\
\text { ical }\end{array}$ & $\begin{array}{l}\text { Factor in } \\
\text { phonological } \\
\text { interference }\end{array}$ & $\begin{array}{l}2, \\
3, \\
4\end{array}$ \\
\hline & es & Lexical & $\begin{array}{l}\text { Factor in } \\
\text { Lexical } \\
\text { interference }\end{array}$ & 5 \\
\hline
\end{tabular}

\section{Documentations}

The function of the documentation method is to make credible the result of observation or interview. In this research, the researcher has used documentation with a recorder and photos.

\subsection{The procedure of Collecting Data}

1. Observation sheet

In this research, the first observation method was done by observing seven of the sixth-semester students of class A and B from English of IAIN Bengkulu as research subjects during five meetings. Then, it is followed by a non-participatory observation technique, combined with the recording technique and note-taking. The non-participatory observation technique means that the writer does not involve in dialogue or conversation [6]. The writer just paid attention to the talks and does not influence the occurrence of the needed data. Students are speaking with their friends and lecturer. Then the writer used the recording technique. The writer used a record in her camera to record the utterances produced by the sixth-semester students at English Department. In note-taking, the writer wrote all the information related to the topic of the research. In addition, the writer used this technique to transfer the recorded data from the camera by listening and replaying the recording and writing down the conversation into a data script in the appendix.

2. Interview

The interview is the activity that involves the interviewer and interviewee where the interviewer was given some questions to be answered by the interviewee. Ary et.al stated ( 1985: 342)“'In an interview, data are collected through face-to-face or telephone interaction between the interviewer and the respondent". Thus, in this case, the interviewer has to conduct collecting data by doing interaction or communication directly. But, it can be conducted face to face or via electronic.

In this research, Researchers used personal interviews. where the purpose of personal interviews is to focus on individual students, meaning that researchers interview English students with seven students from each class are chosen randomly the sixthsemester students class A and B of English education study program of IAIN Bengkulu one by one in doing this the researcher uses structured interview, the structured interview is guided by the general idea of researcher from question list that was arranged previously.

The interview was used to collect the data. in this research, The writer interviewed the informants for two days about the factors that cause interference when they are speaking English.

\subsection{Technique of Data Verification}

Validity in this research is crucial. So, the researcher needs several techniques to make the research data valid. In this research, the researcher used Triangulation to make sure if the data were correct or valid. According to Moleong [5] stated that triangulation is a data verification technique using something that could be in the form of theory, source, etc. which is used only as checking needed or comparing the data. Denzin (1994), stated that there are four kinds of triangulation techniques: data source triangulation, methodology triangulation, investigator triangulation and theoretical triangulation. Triangulation of data sources is certain of the truth informant through a variety of methods and sources of data acquisition. For example, in addition to interviews and observations, the researchers could use participant observation, a written document, an archive, official records, notes or personal writings and photos. In this research, the researcher used data triangulation is the process to recheck and comparing the information by research that gained from distinctive sources. For example, compared the result of an interview with the result of the observation sheet.

\subsection{The technique of Analyzing Data}

After collecting the data, the researcher analyzes the data. Data analysis in qualitative research is a process of categorization, description, and synthesis. Data reduction is necessary for the description and interpretation of the phenomenon under study". In short, data analysis is a systematic process to analyze data that have been collected. Miles and Huberman asserted that the process of analyzing data is done when collecting data began and after the collecting data is finished. It is done continued. Methods of data analysis called Interactive Model which is involved four steps of analysis activity is the cyclical and interactive process [7].

\section{Data collection}

Data collection is the result of data collecting techniques on observation and interview. In this, The researcher took the data collection by observation sheet and interview. The researcher collected the data about the interference in speaking English, linguistics aspects do the sixth-semester students interference when they 
speak English, factors cause interference at the sixth students to class A and B semester students of English education study program of IAIN Bengkulu.

\section{Data Reduction}

Donal Ary (2002: 640) stated that "Data reduction is analyzing the qualitative data via theme analysis or thematic coding while also analyzing the quantitative data via descriptive statistics". In this case, the researcher chose the relevant data of the study and focus on the data that direct solve problems or answer a research problem.

3. Data Display

After reducing the data, the data was organized and arranged in a form by the researcher, so that it can be understood easily. The researcher explained the data display.

4. Conclusion

After all the data were found, it was concluded by the researcher. Then, the data is verified by checking back all the data collection, data reduction and data display while after collecting the data. So in this case the researcher can conclude the data about the language interference in speaking English. On the whole, to analyze the data, the researcher found and collected the data in the field."

\section{FINDINGS AND DISCUSSIONS}

In this chapter, the writer discussed the findings that were found during four meeting times observation and interview. This chapter consists of first language interference in speaking English of sixth-semester students of English Education Study Program of IAIN Bengkulu of A and B class where the students should use full English during presentation and discussion.

\subsection{Findings}

The interference occurs when two languages in different systems come into contact. The data are several sentences that might contain phonological and lexical interference.

This section looks further into the Subject of the research the researcher took seven students per class A and $\mathrm{B}$ of the sixth semester to facilitate data collection about first language interference in speaking English of the sixth-semester students of the English Education Study Program of IAIN Bengkulu, where the students should use full English during presentation and discussion. The writer gave the number for the collected data to make it easier to analyze. The data were taken from the presentation and discussion in the Sociolinguistics class.

\section{Observation on Students' Presentations and Discussions}

Based on the results of researchers researching the class Sociolinguistics A and B sixth semester of English Education IAIN Bengkulu. The writer rewrites sentences containing phonological interference collected from a recorder when the subject of the research presentation and discussion in class of sixth-semester students of English Education Study Program of IAIN Bengkulu class A and B. The Data taken is a frequent and general pronunciation for the Department of English but the research subjects make mistakes in pronunciation.

Pronunciation errors pronounced by research subjects

a. Phonological interference,below are the errors pronunciation made by the sixth semester students of the IAIN Bengkulu class A and B English education that the researcher met when they were discussing and communicating in class. The data that the researcher collected during the four meetings via zoom. Full data can be found inappendix 2: Transcript observation sheet Student's.

The errors pronunciation that were pronounced by the research subjects were as follows:

1) "sociolinguistics"

The word "Sociolinguistics" in S.1.1, she pronounced "Sosiolinguistik". The appropriate pronounciation of it is /sousioulin'gwistiks/.

2) "concerned"

The word "concerned" in S.1.2, she pronounced "khonsernd". The word "concerned" indicated phonological interference made by the student. The appropriate pronounciation is /Kən'sz:rnd/.

3) "eventhough"

The word "eventhough" in S.1.3, she pronounced "iventou". The appropriate pronounciation of it is /'i:vənðəช/.

4) "want"

The word "want" in S.2.1, she pronounced "wan". The correct pronounciation of it is /wpnt/.

5) "refuse"

The word "refuse" in S.2.2, she pronounced "repus". The correct pronounciation of it is /ri' fjoz/.

6) "rubbish"

The word "rubbish" in S.3.1, she pronounced "rubbis". The correct pronounciation of it is /rsbig/.

7) "motivation"

The word "motivation" in S.3.3, she pronounced "motivasyen". The appropriate pronounciation is /, mouti'verfon/.

8) "according"

The word "according" in S.4.1, she pronounced "akkording". The appropriate pronounciation of it is /a'ko:dın/.

9) "person"

The word "person" in S.4.2, she pronounced "person". The correct pronounciation of it is / $\mathrm{P} 3: \mathrm{rsn} /$.

10) "perhaps"

The word "perhaps" in S.5.1, she pronounced "Perhep". The correct pronunciation for that is / pər'hæps /.

11) "knowledge"

The word "knowledge" in S.5.2, she pronounced "knowledc". The correct pronounciation of it is /na:lidz/. 12) "important"

The word "important" in S.6.1, she pronounced "Importan". The appropriate pronounciation is /Im'po:rtnt/. 


\section{3) "participants"}

The word "participants" in S.6.2, she pronounced "participant". The correct pronounciation of it is /pa'tisipənts/.

14) "vocabulary"

The word "vocabulary" in S.7.1, he pronounced "Vokabulary". The correct pronounciation of it is /Və'kæbjəleri/.

15) "particular"

The word "particular" in S.8.1, she pronounced "Partikular". The correct pronounciation of it is /Pər'tıkjələr/.

16) "actually"

The word "actually" in S.8.3, she pronounced "ektually". The correct pronounciation of it is /'ækt Juəli/.

b. Lexical interference, below is lexical interference . lexical interference can occur when one vocabulary interferes with another. In this research, lexical interference made by respodents S.3.2 and S.8.2. Full data can be found inappendix 2: Transcript observation sheet Student's.

S.3.2

"this factors because most budaya and masyarakat menggunakan variasi bahasa yang berbeda." In the sentence above, the respondent says this factors because most budaya and masyarakat menggunakan variasi bahasa yang berbeda. it's indicated lexical interference because when discussing process the student was speaking English that include Indonesian language there.

\section{S.8.2}

"For example different between language yang di gunakan orang berpendidikan dan yang tidak berpendidikan". In the sentence above, the respondent says"For example different between language yang di gunakan orang berpendidikan dan yang tidak berpendidikan. it's indicated lexical interference because when discussing the process the student was speaking English that include the Indonesian language there.

\section{Interview Session}

The results of interviews with 14 sixth semester students of class A and B, as many as seven students in each class are randomly chosen in the sixth-semester students of English education study program IAIN Bengkulu are as follows:

The Question'

1. How do you often use Bahasa or your own vernacular when speaking in daily life?

Question number 1 all respondents answers: Often There some data support this argument, we can see in appendices in the interview.

2. Do you have difficulty in phonology when speaking English?

Question number 2 all respondents answered: Yes here some data support this argument, we can see in the appendix in the interview.

3. What is your difficulty in phonology if you speak English?
For question number 3, the answers to each respondent are different, here some data supports this argument, we can see in the appendix in the interview.

4. What the factor that caused the interference of first language in vowel Phonological when you speak in English?

Made for the students that make the interference when they are speaking, and their answer is as follows:

S.1: Different accent to pronounce it

S.2: Caused by intralingual factor namely factors within the English system itself. The vowel sound system in English has more variations than the sound system in Indonesian. In addition, the inconsistency of the English vowel sound system also causes learners to make mistakes.

S.3: Because in my daily life I use my first language in communicating, of course this causes my vocals in English are still not good

S.4: Factors that influence are the low interests have and lack of support in the environment around me.

S.5: The factors that cause language disorders are the way it is pronounced and the accent is different from Indonesian

S.6: The limited vocabulary a person

S.7: Dialect spoken in the first language

S.8: Difficulty in pronouncing every word and the lack of unfamiliarity in pronouncing it

S.9: Habit factors and lack of try and trying, train us to speak English more fluently.

S.10: Factor habit dan mother tongue

S.11: Influenced by my Indonesia and I don't know the correct pronounciation.

S.12:Different phonemic system, different pronunciation of equivalent phonemes

S.13:The cause of the problem is the inappropriate phonology made by the when i produce english sounds

S.14:The interlingual factor, The overextension of analogy, and Transfer of structure.

5. What the factors the caused the interference of first Language in lexical when you speak in English? Question number 5 all respondents answers: lack of vocabulary There some data support this argument, we can see in appendinces in interview.

\subsection{Discussion}

Based on Chapter II, the researcher has described the definition of interferences. Phonological interference happens when a bilingual speaker perceives and reproduce a phoneme of one language in terms of another language [8]. At the phonological level, the problem of interference concerns how a speaker perceives and reproduces the sounds of one language in terms of another. Weinreich [2] says that lexical interference can occur when one vocabulary interferes with another. Based on the findings above, the types of pronunciation errors that are done respond as follows : 
1. Types of Interference

a. Phonological interference, In this research, interference at the phonological level can cause the actual word(s) said by the respondent(s) turns into another word(s) that has been interfered with by the respondente mother tongue and it causes some errors to the voice transcription.

1) "sociolinguistics"

In this sentence "would like to share about sociolinguistics" there is an error pronunciation made by S.1.1. Namely the word "Sociolinguistics" in S.1.1, she pronounced /Sosiolinguistik/. This happens because the " $v$ " doesn't exist in Indonesian and is not in the word "Sociolinguistics. So that, the student tends to speak "Sosiolinguistik" for English "Sociolinguistics" as the written form. The appropriate pronunciation of it is /sousioulin'gwistiks/.

\section{2) "concerned"}

In this sentence "It is khonsernd on how people use the language in the social context" there is an error pronunciation made by S.1.2. Namely the word "concerned" in S.1.2, she pronounced /khonsernd/. The word "concerned" indicated phonological interference made by the student. As we know that in Indonesian, the way we pronounce words is the same as the written form, it's different from English and the pronunciation of words sometimes it's different from the written form. So that, in speaking English, the student tends to speak "khonsernd" for English "concerned" as the written form. The appropriate pronunciation is /Kon'sz:rnd/.

3) "eventhough"

In this sentence "Iventou many varieties Language" there is an error pronunciation made by S.1.3. Namely the word "even though" in S.1.3, she pronounced /iventou/. This happens because the " $\delta$ " doesn't exist in Indonesian. So that, the student tends to speak "iventou" for English "even though" as the written form. The appropriate pronunciation of it is /'i:vənðِəo/.

4) "want"

In this sentence "I wan try answers your questions, about factor sociolinguistics" there is an error pronunciation made by S.2.1. Namely the word "want" in S.2.1, she pronounced /wan/. This indicated phonological interference because in speaking English, the student tends to speak "wan" for English "want" as the written form. The " $\mathrm{p}$ " in English is pronounced like "o" in Indonesian. The correct pronunciation of it is /wont/.

5) "refuse"

In this sentence "Repus should be deposited in the respectable provided" there is an error pronunciation made by S.2.2. Namely the word "refuse" in S.2.2, she pronounced /repus/. This indicated phonological interference because in speaking English, the student tends to speak"repus" for English "refuse" as the written form. The correct pronunciation of it is /ri'fjoz/.

6) "rubbish"

In this sentence "Put your rubbis in the bin" there is an error pronunciation made by S.3.1. Namely the word "rubbish" in S.3.1, she pronounced /rubbis/. As we know that in Indonesian, the way we pronounce words is the same as the written form, it's different from English in that the pronunciation of words sometimes it's different from the written form. The word "rubbish" indicated phonological interference because the written form is "rubbish". So that, in speaking English, the student tends to speak "rubbis" for English "rubbish". The correct pronunciation of it is $/ \mathrm{r} \underline{\underline{b I}} \mathrm{~g} /$.

\section{7) "motivation"}

In this sentence "look at the initial motivasyen for its development, sociolinguistics" there is an error pronunciation made by S.3.3. Namely the word "motivation" in S.3.3, she pronounced /motivasyen/. The appropriate pronunciation is /,movtı'veIfon/. The "əひ" and "eI" are called diphthong in English, diphthong consists of movement or glide from one vowel to another. This indicated phonological interference because the student transferred her first language phonetic element when speaking English.

8) "according"

In this sentence "akkording to Jendra (2010) Sociolinguistics is a branch of linguistics that takes language as a subject of study" there is a error pronunciation made by S.4.1. Namely the word "according" in S.4.1, she pronounced /akkording/. This indicated phonological interference because in speaking English, the student tends to speak "akkording" for English "according" as the written form. The appropriate pronunciation of it is /a'ko:dıy/.

\section{9) "person"}

In this sentence "It is often shocking to realize how extensively we may judge a person background" there is an error pronunciation made by S.4.2. Namely the word "person" in S.4.2, she pronounced /person/. As we know that in Indonesian, the way we pronounce words is the same as the written form, it's different from English in that the pronunciation of words sometimes it's different from the written form. The word "person" indicated phonological interference because the written form is "person". So that, in speaking English, the student tends to speak "person" for English "person". The correct pronunciation of it is / $\mathrm{P}_{3}: \mathrm{rsn} /$.

10) "perhaps"

In this sentence "like their region, social, or ethnic origin or perhep even their gender" there is an error pronunciation made by S.5.1. Namely the word "perhaps" in S.5.1, she pronounced /Perhep/. This indicated phonological interference because in speaking English, the student tends to speak "Perhep" for English "perhaps". After all, students think every English word changes its pronunciation sound when pronounced in English such as the word "a" is replaced with "e" in the word "perhaps. The correct pronunciation for that is / pər'hæps /. 
11) "knowledge"

In this sentence "their knowledc of most other aspects of language" there is an error pronunciation made by S.5.2. Namely the word "knowledge" in S.5.2, she pronounced /knowledc/. This indicated phonological interference because in speaking English, the student tends to speak "knowledc" for English "knowledge" as the written form. The correct pronunciation of it is /na:lidz/.

12) "important"

In this sentence "of the interaction (informative, social) may be importan" there is an error pronunciation made by S.6.1. Namely the word "important" in S.6.1, she pronounced /Importan/. The word "Importan" indicated phonological interference made by the student. As we know that in Indonesian, the way we pronounce words is the same as the written form, it's different from English in that the pronunciation of words sometimes it's different from the written form. So that, in speaking English, the student tends to speak "importan" for English "important" as the written form. The appropriate pronunciation is /Im'po:rtnt/.

13) "participants"

In this sentence "The participant" there is an error pronunciation made by S.6.2. Namely the word "participants" in S.6.2, she pronounced /participant/. This indicated phonological interference because in speaking English, the student tends to speak "participant" for English "participants" as the written form. The correct pronunciation of it is /pa'tisipənts/.

14) "vocabulary"

In this sentence "to identify the linguistic variation involved (e.g.vokabulary, sounds, grammatical constructions, styles, dialects, languages)" there is an error pronunciation made by S.7.1. Namely the word "vocabulary" in S.7.1, he pronounced /Vokabulary/. This indicated phonological interference because in speaking English, the student tends to speak "Vokabulary" for English "vocabulary" as the written form. The correct pronunciation of it is /Və'kæbjəleri/.

15) "particular"

In this sentence "Partikular language variations that have a pleasing tone, full of pretense" there is an error pronunciation made by S.8.1. Namely the word "particular" in S.8.1, she pronounced /Partikular/. This indicated phonological interference because in speaking English, the student tends to speak "Partikular" for English "particular" as the written form. The correct pronunciation of it is /Pər'tıkjələr/.

16) "actually"

In this sentence "ektually a person's speaking style, such as firm tone, enjoy tone, in a high tone or with a flat face" there is an error pronunciation made by S.8.3. Namely the word "actually" in S.8.3, she pronounced /ektually"\%. As we know that in Indonesian, the way we pronounce words is the same as the written form, it's different from English in that the pronunciation of words sometimes it's different from the written form. The word "ektually" indicated phonological interference because the written form is "actually". So that, in speaking English, the student tends to speak "ektually" for English "actually". The correct pronunciation of it is /'ækt fuəli/.

b. Lexical Interference, Weinreich [2] says that lexical interference can occur when one vocabulary interferes with another. In this research, lexical interference is made by respondents S.3.2 and S.8.2.

S.3.2

"This factors because most budaya and masyarakat menggunakan variasi bahasa yang berbeda."

In the sentence above, the respondent says this factors because most budaya and masyarakat menggunakan variasi bahasa yang berbeda. it's indicated lexical interference because when discussing the process the student was speaking English that include the Indonesian language there. Thus, the correct sentence is this factors because most cultures and societies use a variety of different languages.

S.8.2

"For example different between language yang di gunakan orang berpendidikan dan yang tidak berpendidikan."

In the sentence above, the respondent says"For example different between language yang di gunakan orang berpendidikan dan yang tidak berpendidikan. it's indicated lexical interference because when discussing the process the student was speaking English that include the Indonesian language there. Thus, the correct sentence is, For example, the difference between the language used by educated people and uneducated people.

\section{Factors Causing Interference}

After getting data from interviewing respondents who make interference in phonology and lexical like respondents S.1, S.2, S.3 S.14.Based on the data that the writer got from the interview, two factors are causing first language interference in speaking English of Sixth Semester Students of English Education Study Program of IAIN Bengkulu They are:

a.Lack of knowledge

b.The limited vocabularies of target language mastered by a learner

\section{CONCLUSION}

Based on the findings and discussions in the previous chapter, the writer can conclude that: Interference occurs in linguistic aspects, such as phonological and lexical 
interference. Some deviations mostly occur in bilingual speakers. As a result, when the students speak, they transfer several elements of Indonesian into the English systems. Factors causing interference are the lack of knowledge and the limited vocabularies of the target language mastered by a learner.

\section{REFERENCES}

[1] Weinreich, Uriel. (1953). Languages in Contact: Findings and Problems. New York:

MoutonPublishers.

[2] Weinreich. (1968). Languages in Contact: Findings and Problems. The Hague: Mouton.[Originally published as Publications of the Linguistic Circle of New York, no. 1,1953.]

[3] Alkhudiry, R. I., Al-Ahdal, A. A. M. H., \&Alkhudiry, R. (2020). Analysing EFL Discourse of Saudi EFL learners: Identifying Mother Tongue Interference. The Asian ESP Journal, 89. Retrieved from https://journal.uniku.ac.id/index.php/IEFLJ/article/ view/3425

[4] Gregory, Guest and Elizabeth. (2012). Collecting Qualitative data: A Field Manual for Applied Research Paperback. United State of America: Sage Publication Inc.

[5] Lexy. J. Moleong, (1991), Metodologi Penelitian Kualitatif, Bandung, rejawali press.

[6] Sudaryanto. (1993). Metodedan Aneka Teknik Analisis Bahasa (Pengantar Penelitian Wahana Kebudayaan secara Linguistik). Yogyakarta: Duta Wacana University Press.

[7] Miles, B. Matthew and Huberman, A. Michael. (1994). Qualitative Data Analysis: An

Expended Sourcebook. California: Sage Publications

[8] Chaer, Abdul and Agustina, Leoni. (2004). SosiolingistikPerkenalanAwal.

Jakarta: RinekaCipta. 